\title{
海藻由来フコキサンチンの抗肥満作用
}

\section{Anti-obesity effect of fucoxanthin from brown seaweed.}

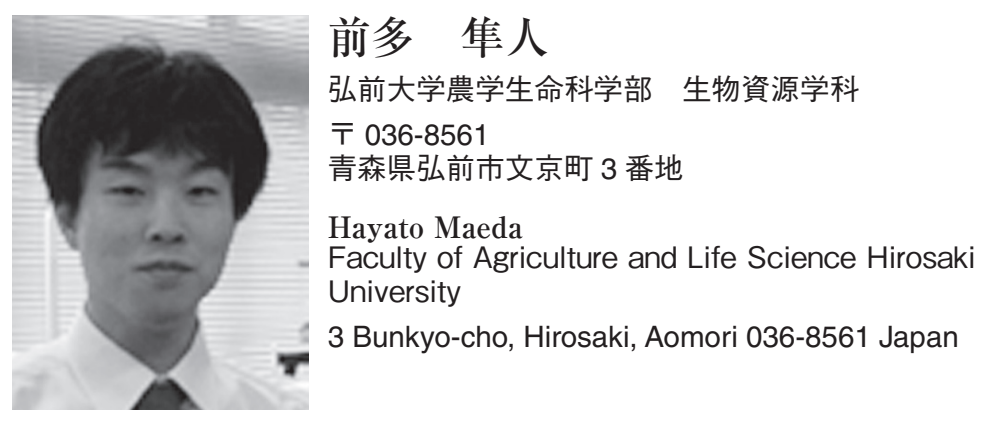

論文要旨：フコキサンチンはワカメやコンブなどの褐藻類に特徵的に含まれる, カロテノイドの一種であ る。近年, 抗肥満, 抗糖尿病, 抗酸化, 抗がん, 血管新生抑制作用など, フコキサンチンの様々な生理機能 が報告されている。これらの機能の中でも脂肪組織を介した抗肥満, 抗糖尿病作用は特に注目されている。 フコキサンチンは, 肥満による様々な疾患の原因となる白色脂肪組織の肥大化を抑える。その作用機構とし て uncoupling protein 1(UCP1) タンパク質の, 白色脂肪組織での異所性の発現誘導が考えられている。また, 脂肪組織から分泌され体内の組織のインスリン抵抗性の惹起に関わるアデイポサイトカインの分泌調節や, 筋肉組織での糖取り込みの正常化により抗糖尿病効果を示す。近年ではフコキサンチンの体内動態とそれら 代謝物による作用も明らかになりつつある。本項では特にこのようなフコキサンチンによる脂肪組織や筋肉 組織を介した抗肥満作用, 抗糖尿病作用の作用機構について解説する。

\begin{abstract}
Obesity, which results from an imbalance between energy intake and energy expenditure, becomes a major health risk factor, causing numerous and various diseases such as diabetes, hypertension, and cardiovascular diseases. Recently, a specific component in brown algae has garnered much attention for its anti-obesity and anti-diabetic effects attributable to a unique mechanism. Fucoxanthin, a carotenoid found in brown algae such as Undaria pinnatifida and Sargassum fulvellum, induces uncoupling protein 1 (UCP1) expression in white adipose tissue (WAT). UCP1 is an inner membrane mitochondrial protein that can dissipate energy through oxidation of fatty acids and heat production. Furthermore, fucoxanthin improves insulin resistance and ameliorates blood glucose levels through down-regulation of adipocytokines related to insulin resistance in WAT and up-regulation of glucose transporter 4 (GLUT4) in skeletal muscle. Fucoxanthin is a beneficial compound for the prevention of the metabolic syndrome.
\end{abstract}

Key words: fucoxanthin, brown algae, carotenoid, anti-obesity, anti-diabetes, UCP1

\section{1 はじめに}

フコキサンチン (Fucoxanthin) はワカメやコンブ, ヒジキなどの褐藻類に特徴的に含まれるカロテノイドの 一種である。光合成において青緑色域（480～540 nm） の光を吸収する補助色素として働いている。フコキサン チンの構造上の特徵としてはアレン構造を有することが あげられる。アレン構造とは 3 つの炭素原子の間に 2 重 結合が連続した構造を指す（Fig. 1)。アレン構造を有す

連絡者：前多 隼人

E-mail : hayatosp@cc.hirosaki-u.ac.jp
るカロテノイドは, フコキサンチンの他にはフコキサン チンの代謝物であるフコキサンチノールやアマローシア キサンチン $\mathrm{A}$ ，野菜類に含まれるネオキサンチンなど ごく限られたものである。フコキサンチンの生理機能と しては, 抗酸化作用 ${ }^{1)}$ や, 白血病 ${ }^{2)}$, 前立腺癌 ${ }^{3)}$, 結腸 がん抑制作用 ${ }^{4)}$, 血管新生抑制作用 ${ }^{5)}$, 抗炎症作用 ${ }^{6)}$, 肝臓での DHA 合成促進作用 ${ }^{7)}$ などが報告されている。 本項ではフコキサンチンの有する様々な機能のうち, 特 に抗肥満, 抗糖尿病作用について解説する。 
褐藻類
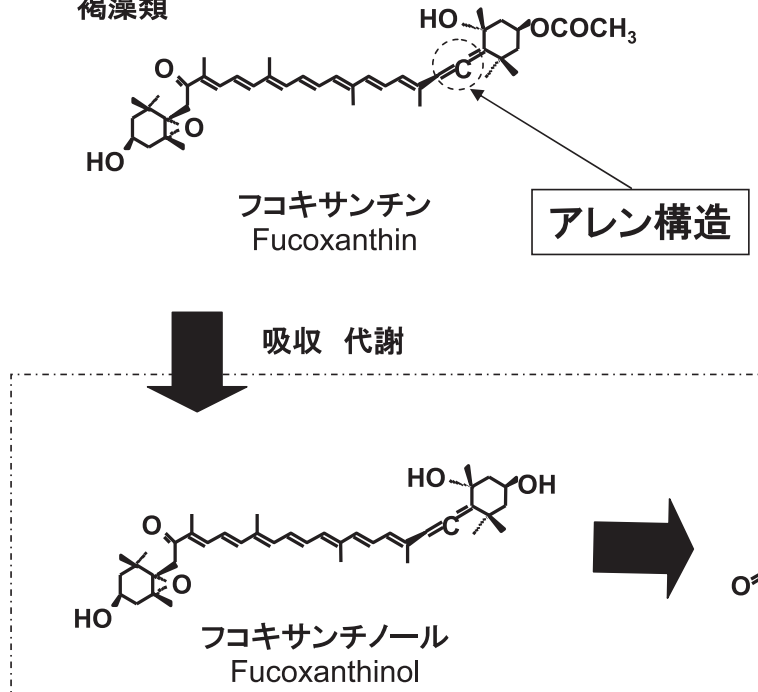

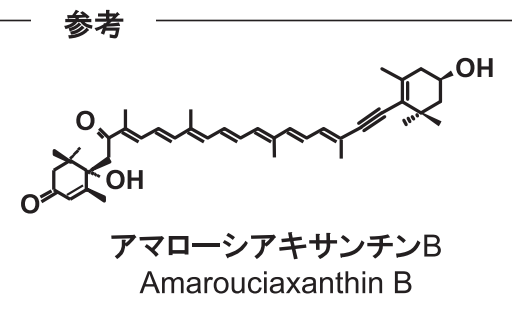

Amarouciaxanthin $B$

Fig. 1 フコキサンチンと消化吸収後の代謝物の構造

\section{2 フコキサンチンによる内臓脂肪減少作用}

肥満を原因として糖尿病，高血圧，高脂血症などが合 併した状態であるメタボリックシンドロームは, 先進国 や，近年経済発展が著しい国々で問題となっている。そ のため，肥満を予防することはこれらの疾患を減少させ る上で極めて重要である。肥満状態では脂肪組織に過㮃 に脂肪が蓄積され，脂肪細胞の肥大化が㧍こる。肥大化 した脂肪細胞からは tumor necrosis factor $\alpha$ (TNF- $\alpha$ ) やレジスチン, monocyte chemoattractant protein 1 （MCP-1）といったアデイポサイトカインが多量に産生, 分泌される。これらのアデイポサイトカインは高血圧や 動脈硬化，インスリン抵抗性を惹起することから，過剩 な脂肪蓄積を抑制することや，蓄積した脂肪を減少させ ることが重要である。肥満を解消する方法としては食事 管理や運動が効果的ではあるが，急な生活習慣の改善は 難しいケースが多い。また肥満予防食品として糖質や脂 質の腸管内での吸収を阻害するものもあるが，食品中に 含まれる必須栄養素の吸収も阻害されてしまう恐れもあ る。そのため, 脂肪細胞での脂質代謝を促進させ，余分 に蓄積された脂質を減少させることは有効な方法である と考えられる。

フコキサンチンを含むワカメ油（ワカメ脂質成分）を 糖尿病肥満モデルマウス（KK- $A^{y}$ マウス）に投与すると, 白色脂肪組織 (WAT) 重量の増加か影著に抑制された ${ }^{8)}$ 。 更にこの活性成分を検討した結果，ワカメ油に含まれる フコキサンチンであることが明らかとなった。KK- $A^{y}$ マウスにフコキサンチンを $0.1 \%, 0.2 \%$ 含有飼料を投与
すると, 投与濃度に依存し体重増加と WAT の増大が 抑制され，それに伴いWAT での脱共役タンパク質 1 (uncoupling protein 1, UCP1) の発現が兄進した（Fig. 2)。

脂肪組織には WAT に加え褐色脂肪組織（BAT）が 存在し, 互いに異なった生体機能を示す。WAT は精巣 や卵巣などの生殖巣, 腸管や腎臓周囲に存在する脂肪組 織であり，過剩なエネルギーをトリアシルグリセロール の形で蓄積する役割がある。一方，BAT は肩部にごく 少量あり, 脂肪を分解し熱を産出することで体温を保持 するとともに，余分なカロリーを消費する機能を持って いる。この機能はBAT 中のミトコンドリアの内膜に存 在するUCP1によるものである（Fig. 3）。これまでに， 肥満動物ではUCP1 の機能が低下していることや, 多食 しても肥満にならない動物では BAT 中の UCP1 発現量 が増加していることが報告されている ${ }^{9)}$ 。また，人為的 にUCP1 の発現を低下させたマウスは肥満になるのに対 し，高発現マウスは太りにくいという報告がある ${ }^{10,11) 。 ~}$ 更に最近, 成人に抏いてもBATが存在し, エネルギー 消費に関わっていることが明らかにされた ${ }^{12)}$ 。従って

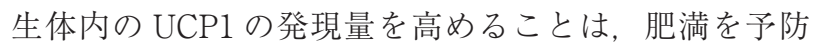
する上で有効な方法と期待される。また，ある種の薬剤 や遺伝子改変動物では, 本来は UCP1の発現しない WAT でUCP1 の異所性の発現誘導がなされること，そ れに伴う熱産生によるエネルギー消費増大が示唆されて いる ${ }^{13)}$ 。特にWAT は内臟脂肪の大部分を占め, BAT と比較して大きな組織である。そのためWAT 中に UCP1 が誘導され脂肪燃焼が引き起これば, 極めて効果 
(A)白色脂肪組織重量

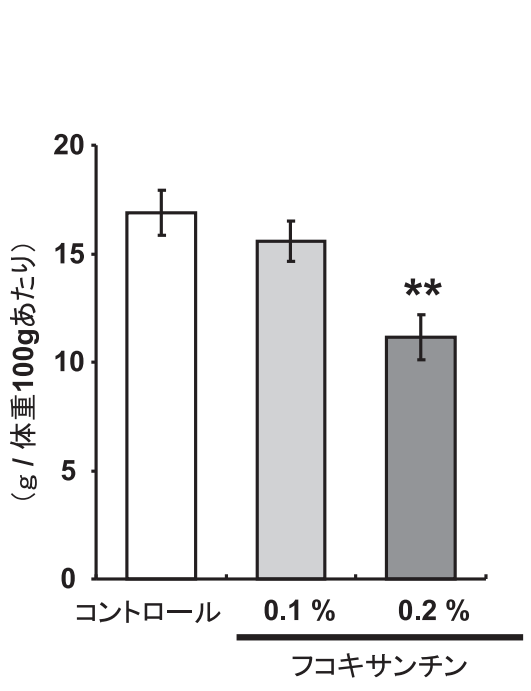

(B)白色脂肪組織でのUCP1タンパク質の発現
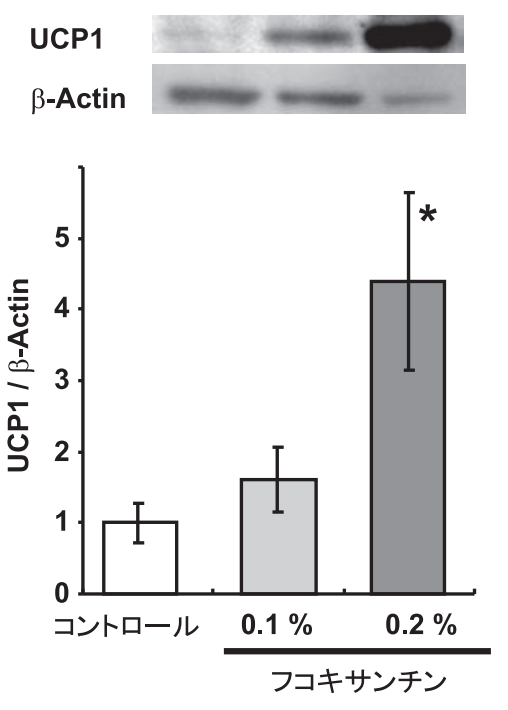

*P<0.05 vs コントロール **P<0.01 vs コントロール

Fig. 2 フコキサンチンを投与したマウスの白色脂肪組織重量と白色脂肪組織での UCP1 タンパク質の発現

的な肥満予防法と考えられる。

これまでの報告で食品由来の成分で UCP1の発現を 高めるものとしては, カプサイシンやカプシエイトなど

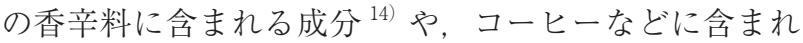
るカフェイン ${ }^{15)}$ ，及び DHA や EPA などの高度不飽和 脂肪酸 ${ }^{16)}$ の報告例があるが，いずれも BATにおける UCP1 の誘導作用である（Fig. 3）。また，ヒトでは年齢 とともにBATが減少する。フコキサンチンのような WAT での UCP1 の発現誘導作用は, 他のカロテノイド を含めた食品成分において報告例がない。このことから，
フコキサンチンの作用は, 新たな肥満抑制機構として大 変興味深い。

フコキサンチンによる UCP1 発現による脂肪蓄積の 抑制効果の作用メカニズムとして，脂肪細胞の膜上の夕 ンパク質である $\beta 3$ アドレナリン受容体 (Adrb3) の発 現六進が考えられる。C57/BL6J マウスに30\%脂質を含 む高脂肪食を投与し，食事性の肥満を誘発させた。その 後フコキサンチンを約 $0.1,0.2 \%$ 含むワカメ油含有高脂 肪食を投与したところ, 投与濃度に依存してWAT 重 量が減少した ${ }^{17)}$ 。その際, WAT中の Adrb3の mRNA

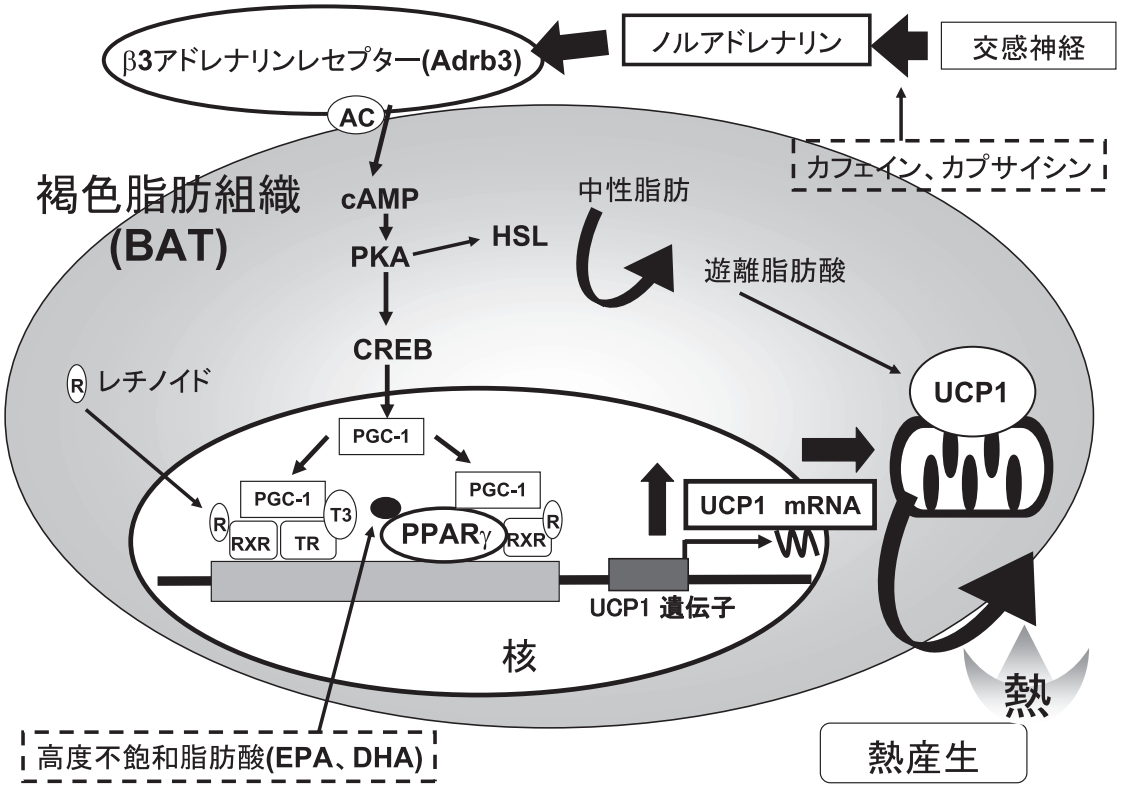

Fig. 3 褐色脂肪組織での UCP1による熱産生のメカニズムと食品成分の作用 
の発現レベルの上昇が確認された。また，肥満糖尿病モ デルマウス $\mathrm{KK}-A^{y}$ マウスでも Adrb3 の mRNA の発現 上昇が確認されている。Adrb3 は交感神経からの運動 刺激により脂肪細胞での脂肪分解を促す働きをする受容 体である。Adrb3 のアゴニスト刺激により脂肪細胞で の脂質分解と BAT での UCP1 の発現上昇が誘導される ことが明らかとなっている。これらのことから WAT での UCP1 発現調節にはAdrb3 の関与が考えられ，更 なる検討が進められている。

\section{3 フコキサンチンの抗糖尿病作用}

肥満が進行すると, 肝藏や筋肉などの体内の組織での インスリン抵抗性が高まり糖尿病を発症する。糖尿病の 場合，血糖の取り込みと代謝が低下することにより血糖 值が上昇し，細小血管症（網膜症, 腎症, 神経障害）を もたらす。また，他の肥満に関連する疾患である高血圧 や高脂血症を治療するための薬剤はめまぐるしく発展し ているのに対し, 糖尿病の治療に関しては未だに生活習 慣の是正に強く依存している。従って，体内のインスリ ン抵抗性を改善させ, 血糖の細胞内の取り込みと代謝を 促進する成分の探索が重要である。

糖尿病肥満モデルマウスである $\mathrm{KK}-A^{y}$ マウスでは, 体重やWAT の増加と共に血糖值の上昇や高インスリ ン血症が認められる。KK- $A^{y}$ マウスにフコキサンチン を投与すると，血糖值と血中インスリン濃度の顕著な改 善効果が示された ${ }^{18)}$ 。このような作用は正常マウスで は観察されず，肥満糖尿病マウスに対してのみ作用が見
られた ${ }^{19)}$ 。また高脂肪食で食事性肥満を誘発させたマ ウスにおいても, 血糖值と血漿インスリン濃度の改善作 用が示された $(\text { Fig. 4 })^{17)}$ 。フコキサンチンによるこのよ うな作用のメカニズムとして，脂肪細胞から分泌される アディポサイトカインの発現調節作用が考えられる。肥 満状態の脂肪組織では脂肪細胞にマクロファージなどの 単球細胞の浸潤し, 一種の炎症状態となる。このような 脂肪細胞での慢性炎症状態が TNF- $\alpha$ や Interleukin- 6 な どの炎症性サイトカインの分泌を促し, 各組織のインス リン抵抗性を惹起する。フコキサンチンを投与した $\mathrm{KK}-A^{y}$ マウスでは脂肪細胞でのこれらの炎症性サイト カインの mRNA の発現低下が認められた ${ }^{19)} 。$

また筋肉組織での glucose transporter 4 (GLUT4) による，糖取り込みの改善作用が明らかとなった。血中 のグルコース濃度が高まるとインスリンが分泌され, 筋 肉細胞膜上のインスリンレセプターに作用する。次いで, 細胞質中に存在する GLUT4 が細胞膜へトランスロケー ションし, 血中のグルコースが速やかに筋肉細胞へと取 り込まれる。肥満状態では GLUT4 のトランスロケー ションが抑制されるとともに，GLUT4の発現量自体も 減少することが報告されている ${ }^{20)}$ 。フコキサンチンを 投与した KK- $A^{y}$ マウスでは, GLUT4 の膜移行が誘導さ れた。また，インスリンシグナルの伝達に関る AKT夕 ンパク質のリン酸化と，インスリン受容体の mRNAの 発現量の増加が誘導された ${ }^{21)}$ 。また筋肉組織での脂質 代謝遺伝子の調節に関与する peroxisome proliferator activated receptor $\gamma$ coactivator-1 $\alpha$ (PGC-1 $\alpha)$ の筋肉細
(A) 血糖値

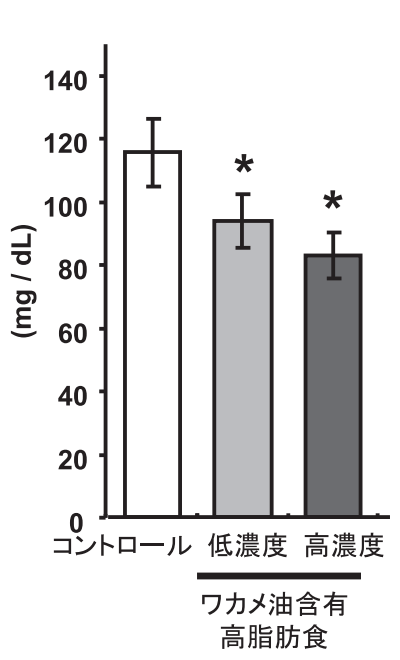

(B) 血漿インスリン值

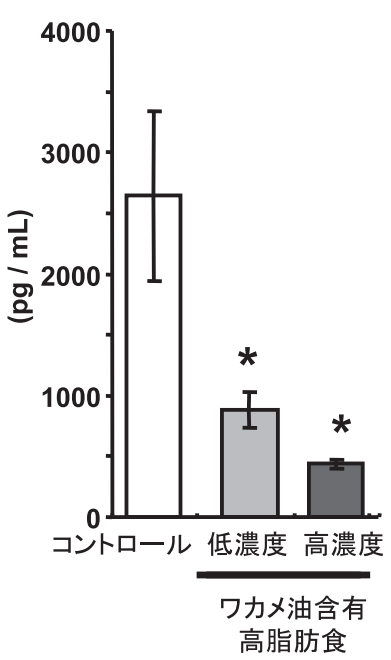

(C)骨格筋組織での GLUT4 のmRNA発現量

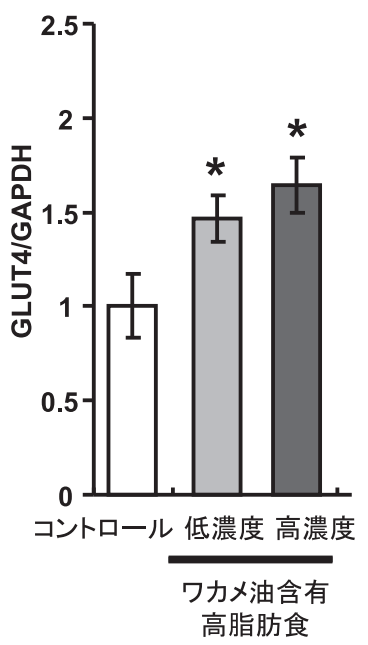

$* P<0.05$ vs コントロール

Fig. 4 高脂肪食による食事性肥満誘導マウスに対するフコキサンチン含有ワカメ油の血糖值, 血漿インスリン值, 及び骨格筋組 織での GLUT4 の mRNA 発現に対する効果 
胞上での発現上昇も確認されている。また，食事性肥満 マウスの骨格筋組織中での GLUT4 の mRNA の発現レ ベルの上昇も確認された $\left(\right.$ Fig. 4 ${ }^{17)}$ 。

これらのことからフコキサンチンはインスリン抵抗性 惹起に関わるアディポサイトカインの分泌抑制と, 筋肉 組織での糖取り込みの改善の両面から, 糖尿病を予防, 改善する働きを示すと考えられる。

\section{4 フコキサンチン代謝物の脂肪細胞での作用}

フコキサンチンは生体内で代謝され，消化管内で加水 分解されてフコキサンチノールに変換された後, 更に肝 臓中でアマローシアキサンチン A へと代謝される (Fig. 1) ${ }^{22)}$ 。また, WAT 中ではフコキサンチノールやアマロー シアキサンチン $\mathrm{A}$ が移行し蓄積していることが確認さ れている。従って，これらのフコキサンチン代謝物が活 性物質として働き，機能を発揮している可能性が高い。 フコキサンチンの代謝物による脂肪細胞での作用を解明 するため, マウス由来 3T3-L1 細胞を用いた in vitroの 検討が進められている。フコキサンチノールを3T3-L1 細胞の分化誘導培地に添加した結果, フコキサンチンと 同様に脂肪滴の蓄積抑制と glycerol-3-phosphate dehydrogenase（GPDH）活性の上昇が抑制された ${ }^{23)}$ 。また, フコキサンチノールとその代謝物であるアマローシアキ サンチン A の脂肪細胞に対する効果を比較した結果, アマローシアキサンチン A の方がその作用が強いこと が明らかとなった ${ }^{24)}$ 。更に脂肪細胞に特徵的に発現上 昇が認められる核内転写因子である peroxisome proliferator-activated receptor $\gamma(\operatorname{PPAR} \gamma)$, 及び転写調節に 関わる CCAAT enhancer binding protein $\alpha(\mathrm{C} / \mathrm{EBP} \alpha)$ の mRNA とタンパク質発現量を調べた結果, アマロー シアキサンチン A を添加した細胞で強く抑制された。 これらのことから, 脂肪組織に蓄積したアマローシアキ サンチン $\mathrm{A}$ は未分化の前駆脂肪細胞の分化を抑え, 脂 肪組織の肥大化抑制の一旦を担っていることが考えられ た。この実験においてアマローシアキサンチン A の類 縁物質であるアマローシアキサンチン B との脂肪細胞 分化抑制効果の比較検討されている。アマローシアキサ ンチン B は, アマローシアキサンチン A がもつアレン 構造を有していない(Fig. 1)。同濃度の検討ではアマロー シアキサンチン $\mathrm{A}$ のみ, 強い脂肪細胞の分化抑制効果 が示した。また，別の報告で果実や野菜中に含まれる各 種カロテノイドの脂肪細胞への分化抑制作用の比較検討 では, アレン構造を有するカロテノイドであるネオキサ ンチンが，3T3-L1 細胞での脂肪蓄積を抑制することが 報告されている ${ }^{25)}$ 。これらの報告から, これまでに述 ベてきたフコキサンチン及びその代謝物の特徵的な抗肥
満効果は, カロテノイド分子中のアレン構造が関係して いると推測されている。

\section{5 フコキサンチンの安全性の検討と臨床試験}

フコキサンチンを摂取した場合の安全性の検討結果が いくつか報告されている ${ }^{26)}$ 。ICR マウスに対して, 30 日間フコキサンチンを 500, $1000 \mathrm{mg} / \mathrm{kg}$ body weight の投与量で反復経口投与試験を行った。その結果, 毒性 や組織学的な異常が確認されなかった。更に変異原性試 験として, ICR マウスヘフコキサンチンを経口投与し， 染色体異常を検査した小核試験では, 異常は認められな かった ${ }^{27)}$ 。また，代謝物であるフコキサンチノールの 変異原性についての復帰突然変異試験（Ames test）に よる検討でも，異常は認められなかった。このような動 物実験をはじめとした検討では, フコキサンチンの安全 性が示されている。

ヒトの血漿中のカロテノイドは $\beta$-カロテン, ルテイ ンの割合が多いが, ある程度はカロテノイドを含む食品 を摂取することで変化するとされている。フコキサンチ ンの場合は, フコキサンチンを含む海藻を 1 週間摂取し た報告では，血漿中にフコキサンチノールがごく微量な 濃度で検出される ${ }^{28)}$ 。

ヒト試験による肥満予防作用についてもいくつか報告 がされている。肥満女性に対してフコキサンチンを一日 あたり $2.4 \mathrm{mg}$ 投与し 16 週間試験を行った ${ }^{29)}$ 。その結果, フコキサンチン投与群では有意な体重の減少と, 胴回り のサイズの低下, 体脂肪, 肝臓脂肪, 及び血漿トリアシ ルグリセロール濃度の低下が認められた。更に休息時の エネルギー消費量の上昇が確認された。この結果から， ヒトにおいても肥満の予防作用をもつ可能性が示され た。今後, 更なる臨床デー夕の蓄積が望まれる。

このような作用を生かし，フコキサンチンを食品素材 として利用するためには, 物質の安定性を向上させる必 要がある。カロテノイドは一般的に不安定な物質であり, 特に熱や酸, 光刺激により分解されやすい物質である。 Hii らの報告によるとフコキサンチンの安定性の向上に は他のカロテノイドと同様に, 暗所で保つこと, 更に抗 酸化㓮としてアスコルビン酸の添加が有効であるとされ ている ${ }^{30)}$ 。

\section{6 おわりに}

フコキサンチンは脂肪細胞に機能し, 抗肥満, 抗糖尿 病作用を示す。その作用機構の一端として, WATでの UCP1の異所性の発現を介したエネルギー消費の立進 と, アデイポサイトカインの調節が推察された。また, 筋肉組織を介した血糖值上昇の抑制作用のメカニズムも 
解明されつつある。最近ではヒト試験の報告，また代謝 物の作用も報告され，作用機構が明らかになってきた。 今後はフコキサンチンの原料となる海藻種の探索や効率 の良い抽出方法の確立, 更には安定性を考慮した加工法 の開発が課題である。海藻は食料資源の他, $\mathrm{CO}_{2}$ の吸収 による地球環境の保全, バイオエタノールなどのエネル ギー原料素材としても注目され始めている。更に先の東 日本大震災において，大きな打撃を受けた三陸沿岸域の 貴重な水産資源でもある。今後，海藻に含まれるフコキ サンチンを利用した食資源の付加価值の向上や, フコキ サンチンの多機能性の更なる解明と, その活用を目指し た研究の進展が期待される。

\section{文 献}

1) Sachindra NM, Sato E et al., J Agric Food Chem., 55, 8516-22 (2007)

2) Hosokawa M, Wanezaki, S et al., Food Sci. Technol. Res., 5, 243-6 (1999)

3) Kotake-Nara E, Kushiro M et al., J Nutr., 131, 3303-6 (2001).

4) Das SK, Hashimoto T et al., Biochim Biophys Acta., 1726, 328-35 (2005)

5) Sugawara T, Matsubara K et al., J Agric Food Chem., 54, 9805-10 (2006).

6) Kim KN, Heo SJ et al., Eur J Pharmacol., 649, 369-75 (2010).

7) Tsukui T, Konno K et al., J Agric Food Chem., 5025-29 (2007).

8) Maeda H. Hosokawa M et al., Biochem Biophys Res Commun., 332, 392-97 (2005).

9) Cannon B \& Nedergaard J., Physiol Rev., 84, 277-359 (2004).

10) Nagase I, Yoshida T et al., J Clin Invest., 97, 2898-904 (1996).

11) Cederberg A, Grønning LM et al., Cell., 106, 563-73
(2001).

12) Saito M, Okamatsu-Ogura Y et al., Diabetes., 58, 152631 (2009).

13) Sasaki N, Uchida E et al., J Vet Med Sci., 60, 465-9 (1998).

14) Masuda Y, Haramizu S et al., J Appl Physiol., 95, 240815 (2003)

15) Kogure A, Sakane N et al., Clin Exp Pharmacol Physiol., 29, 391-4 (2002).

16) Kawada T, Kayahashi S et al., J. Agric. Food. Chem., 46, 1225-7 (1998).

17) Maeda H, Hosokawa M et al., Mol Med Report., 2, 897902 (2009)

18) Maeda H, Hosokawa M et al., J Agric Food Chem., 55, 7701-6 (2007)

19) Hosokawa M, Miyashita T et al., Arch Biochem Biophys., 504, 17-25 (2010).

20) Zorzano A, Santalucia T et al., Gen Pharmacol., 31, 705-13 (1998).

21) Nishikawa S, Hosokawa M et al. Phytomedicine., 19, 389-94 (2012).

22) Asai A, Sugawara T et al., Drug Metab Dispos., 32, 205-11 (2004)

23) Maeda H, Hosokawa M et al., Int J Mol Med., 18, 14752 (2006).

24) Yim MJ, Hosokawa M et al., J Agric Food Chem., 59, 1646-1652 (2011).

25) Okada T, Nakai M et al., J Oleo Sci., 57, 345-51 (2008).

26) Beppu F, Niwano Y et al., J Toxicol Sci., 34, 501-510 (2009).

27) Beppu F, Niwano Y et al., J Toxicol Sci., 34, 693-698 (2009).

28) Asai A, Yonekura L et al., Br J Nutr., 100, 273-277 (2008).

29) Abidov M, Ramazanov $Z$ et al., Diabetes Obes Metab., 12, 72-81 (2010).

30) Hii S-L, Choong P-Y et al., Australian Journal of Basic and Applied Sciences, 4, 4580-4 (2010). 